right at subsequent sessions. We seek, therefore, to ascertain the facts relating to the supply of ink for the exchequer in the thirteenth and fourteenth centuries. Unfortunately, with the exception of the Pipe Rolls and Chancellors' Rolls, the records of the exchequer of the reign of Henry III are in such a state of confusion, and so greatly need rearrangement, that it is impossible to draw from them as much information as might have been hoped. The records now known as Exchequer Liberate Rolls show that in that reign a sum of forty pence was paid half-yearly for ink, but the name of the person to whom it was paid is not mentioned. Madox has printed in his History of the Exchequer ${ }^{8}$ an entry from a record, from which we learn that the payment was made as early as the year 9 Henry III. The Issue Rolls of 4 Edward I discover that it was the sacrist of Westminster who then received this half-yearly sum of forty pence for ink used in the exchequer. A few years later, however, it was the precentor who received it, and he was still receiving it in the year 18 Edward III, ${ }^{9}$ but in 25 Edward III again we find the sacrist resuming his privilege. ${ }^{10}$ Towards the end of the reign of Edward III the sacrist provided the ink not only for the two exchequers, but also for the office of privy seal."1 His remuneration nevertheless remained unchanged.

The facts which I have recited seem to me to justify the retention of the old reading Westmonasterii. The change from the sacrist to the precentor and from the precentor to the sacrist again need occasion no surprise. It was a matter which concerned the monastery and not the exchequer. Both the sacrist and the precentor required ink, the former for writing his accounts, the latter for preparing his service books. There were various arrangements in different monsateries with respect to such small matters; but it may be noticed that in the abbey of Evesham it was the duty of the precentor to find the ink for all the writers of the monastery. ${ }^{12}$ The history of the internal government of Westminster Abbey remains to be written. $\quad$ G. J. TURnRr.

\title{
The Date of Composition of William of Newburgh's History.
}

Is the preface to the first volume of his edition of William of Newburgh's Historia Rerum Anglicarun Mr. R. Howlett gave nine reasons from which he drew the following conclusion:-

These circumstances, taken in connexion, seem to indicate that the

- Vol. ii. p. a11.

- Issue Roll, Pells, no. 198 (Easter, 18 Ed. III), memb. 19.

10 Ioid. no. 205 (Easter, 25 Ed. III, July, 'Livories').

"F. Devon, Issue Roll of Thomas de Brantingham, pp. 209, 170.

"W. D. Maeray, Chronicon Abbatiae de Evesham (Rolls Series), p. 210. 
present work was begun in or before 1196, and that shortly after May 1198 William of Newburgh went to his rest, leaving his work unrevised.

$\Delta$ recent study of the Historia Rerum Anglicarnm, undertaken with special regard to the question of its date, has led me to form a different opinion, based on evidence contained in the book itself.

I will deal with the direct evidence under six heads.

I. The 'Epistola praefationalis et apologetica' prefixed to William's history in all the manuscripts is addressed to Ernald, abbot of Rievarax. This letter was evidently written not, like most prefaces or dedicatory epistles, after the conclusion of the work which it introduces, but before that work was begun; it seems, in fact, to have been written in answer to a letter in which Ernald had urged William to undertake that work (Litteras sanctitatis vestrae suscepi quibus mihi studium et operam revum memorabilium . . . conscribendarum dignatur ingerere . . Itaque . . opus inizunctum aggrediar). Ernald, abbot of Melrose, was elected abbot of Rievaux on Thursday, 2 March 1189, and resigned in 1199. ${ }^{1}$ The day and month of his resignation are not stated, but the entry is placed between that of Richard I's desth and that of John's coronation.

II. In lib. i. 15 William mentions Roger, abbot of Byland, qui adliuc superstes est, in senectute uberi, administrationis suae annis circiter quinquaginta et septem expletis. The 'Fundatio Domus Bellalandae" states that Gerold, abbot of Byland,

profectus est ad capitulum generale Savigneiense A.D. MOXLII circa fastum 8. Johannis Baptistae . . . et . . o obiit in reditu de capitulo Sarygneii vi kalendas Marcii . . . Eo anno sucoessit ei dompnus Rogerus. ... Praefuit autem abbers $\mathrm{B}$. in officio pastorali Bellalanda ... per quinquaginta quatuor annos et amplius a die ordinstionis suse usque ad deorepitam aetatem, et tunc cessit officio suo. . . . Vixit autem dictus $\mathbf{B}$. abbas post cessionem surm in domo Bellelandar una nobiscum fere iii annos, et tunc quievit in Domino.

Thus Abbot Gerold died 24 Feb. 1149; Roger succeeded him in the same year, resigned in 1197, and died at the close of 1199 or early in 1200. Of course, if William's words are to be taken literally, as having been written before Roger's resignation, it follows either that William has made Roger's tenure of office too long by three years or that the writer of the 'Fundatio Bellalandae' has written quinquaginta quatuor et amplius when he meant, or should have mesnt, quinquaginta septem. As, however, Roger continued to live in his old abbey after his resignation, William's phrase may very well moan simply that when it was written 'about fifty-seven years' had elapsed since Roger was elected to the abbacy. This would harmonise with the dates given in the 'Fun-

1 Chron. STolrose, a 1189 and 1199.

SMonast. Angl. r. 350-4.

VOL. IIX. - No. LXXIT. 
datio,'s and indicate that the passage was written shortly before Roger's death, at the end of 1199 or early in 1200.

III. In lib. iii. 7 William writes: Sicque Britones, qui dirc fabulosum dicuntur exspectasse Arturum, nuine sibi cum multa spe nutriunt verum. Arthur of Brittany was captured by John on 1 August 1201, and kept in prison till c. April 1203, when he finally disappeared.

IV. In lib. iv. 26 William relates how Philip Augustus obtained from the bishops of Beauvais and Chartres a divorce from his queen, and proceeds: Et Beluacensis quiden postea Dei iudicio traditus in manus regis Anglorum, eundem satis idoneum expertus est in severitate ultionis Dei ministrum. Carnotensis rero ... Dei adhuc patientia sustinet. The bishop of Beauvais fell into Richard's hands in May $1196 ;{ }^{4}$ Bishop Reginald of Chartres died 8 Dec. 1217."

V. In lib. $\nabla .29$ is recorded the death of William of Longchamp, bishop of Ely. Longchamp died 31 Jan. or 1 Feb. 1197. ${ }^{\circ}$

VI. William of Newburgh's work, in all the manuscripts, comes to an abrupt end with an account of a 'bloody shower' at Châtesu-Gaillard (lib. v. 34). The date of this event is given by Ralph de Diceto (ii. 162) as 8 May 1198.

We thus get the following dates :-

(i.) William's history, in its present form, was begun not earlier than March 1189, and not later than the end of 1199.

(ii.) Lib. i. 15 was written towards the end of 1199 or early in 1200.

(iii.) Lib. iii. 7 was written before the middle of 1203 ; more probably before September 1201.

(iv.) Lib. iv. 26 was written not earlier than the sammer of 1196 and not later than the spring of 1218.

(v.) Lib. v. 29 was written not earlier than February 1197.

(vi.) Lib. $\nabla .34$ was written not earlier than May 1198.

I will now tarn to indirect evidence.

I. Cave's statement' that, 'as some will have it,' William died

\footnotetext{
- A sentence in the 'Fondatio' immediately preceding its mention of Roger's desth may at the first glance raise a doubt as to the soundness of its chronology : 'Nos vero trater Philippas . . a abbas Bellelendase et proximus dicti Rogeri successor, heow scripsimas in anno Domini M.C. nonagesimo octaro, scilicet abbatirationis nostrae secundo, et post transitum Alredi sbbatis de Ryevalle anno tricesimo.' The difficalty here is, however, only superficial. Abbot Philip's next sentence tells of Roger's desth; it is followed by only one more sentence, which concludes his work. He doubtless added these two sentences after Roger's death (i.e. in 1199 or 1200) as a wind-up to the history which ho had written, as he sags, in 1198, the year to which all his other ahronological indications point, save one; and the discrepancy inval red in thet ono-his relerence to the death of Aelred of Rievanx-may easily have been due to an accidental omission of ' secondo' after 'tricesimo.'

- I. Howden, iv. 16. Gallia Christiara, vol. viil. col. 1156.

- R. Diceto, if. 150; Gerv. Cant. i. 648. I Hist. Litt. a 1195.
} 
in 1208 is of no evidential value. We know, however, that William was born in 1136 ('Prooemium'). Now, a man born in 1136 might, of course, be still living, not only at the latest date which can be essigned to lib. iv. 26, viz. 1217-8, but even some years later still. But it is not very likely either that William would be still working at his history at the age of eighty-one, or that, if he really had it in hand for seventeen years and more (and we have seen that it was begun not later than the end of 1199), he would not, at least, have brought it up to what seems the natural termination for the fifth book-the death of Richard I.

II. Some indirect light may be thrown on the question of date by William's attitude towards two of the historical personages of whom he treats. One of these is Arthur of Brittany. There are several indications that William felt a particular interest in Arthur, and that this interest was connected with his views as to the stories and prophecies about the Breton hero-king Arthar which he handles so severely in his preface. William's mental attitude towards delusive prophecies in general-i.e. prophocies which are fulfilled in some sense other than that which their words neturally convey-may be gathered from lib. v. 6.8 $\mathrm{He}$ seems to have regarded them as, to a certain extent, genuine anticipations of futurity, but as being of diabolic origin and therefore deceptive. Among predictions of this kind he evidently ranked the prophecies ascribed to Merlin concerning King Arthur's return; and in speaking of the boy Arthar he uses some expressions which, when taken in connexion with a passage in his preface, indicate that he regarded these delusive prophecies about the mythical Arthar as being fulfilled, in a sense other than that which their words literally implied and in which the 'foolish Bretons' understood them, in the person of the actual one.

Bicque Britones, qui diu fabulosum dicuntur exspectasse Arturam, nuno sibi cum multa spe nutriunt verum, iuxta opinionem quorundam, grandibus illis et famosia de Artaro fabulis prophetatum (lib. iii. 7). Turbatio Britonnm, qui pueralum sibi Artarum sab magno huius nominis omine nutriebsant (lib. v. 18). ${ }^{9}$ Notandum, quod eundem Arturum postea refert [Gaufredus] in bello letaliter vulneratum, regno disposito, ad curanda

- One of the prophecies dealt with in this chapter relates to the death of Btephen, seneschal of Anjou under Richard. The prediction was made during Richerd's captivity, and had been folfilled when the chapter was written. Among other things Stephen was to retsin his office till his death; and so, says William, he did. The Chronicle of Heaut Abbey, i. 289-90, states that Robart of Turnham-about whom it is likely to be well informod-was seneschal of Anjon in 1197; if this statement and William's are both correct, therefore, Steplsen must have died not later than that Jear; he must at any rate, if William's atatement is correct, have been dead before 27 Dec. 1199, for at that date the seneschal of Anjou was William des Roches (Rot. Chart. i. 34).

- Cl. also the references to Arthar in lib. iv. 14 and lib. v. 30. 
vulnera sua abiisse in illam quam Britannicse fingunt fabulas insulam Avallonis; propter metum Britonum non audens eum dicere mortunm quem adhuc vere bruti Britones expectant venturum (' Procemium ').

It is difficult to determine how much or how little political meaning lies veiled in these passages. On the one hand it may very well be argued that William would not have laid so much stress upon young Arthar's position as (in some sense) the substitute for his mythical namesake unless he had, at the time of writing, regarded Arthur's ultimate succession to something far greater than the Breton duchy as at least still possible-in other words, that he would not have written thus after all hope of Arthur's ousting John from the heritage of the Angevins had been extinguished in 1208 . On the other hand I venture to think that William's words do not necessarily imply that he himself had any more expectation of a real fulfilment of the prophecy in the person of the new Arthar than in that of the ancient one. It seems to me possible that the mere fact of the name Arthur being once again borne by a raler of the Bretons was a fulfilment sufficient to satisfy William's own theory of the origin and nature of the prophecy ; and if this were so, his interest in the matter, as bearing upon the questions dealt with in his prefsce, need not have been in any way affected by Arthur's fate, and therefore does not give any additional clue to the date of the passages relating to Arthur. ${ }^{10}$

III. Another personage concerning whom William uses very remarkable language is John Lackland. William twice calls John hostis naturae (lib. iv. 34 and 40). This may be thought a startling description of John to have been written before his accession to the throne or during the first two or three years of his reign, and its application to him in those earlier days may appear more likely to have been made retrospectively by one who had seen something of the later developments of his character, if not in his excesses during the interdict, at least in his treatment of his young orphan nephew. Another explanstion, however, seems to me possible, for the following reasons:

(1) With the first pessage in which William uses the phraseNec Iohannes, ex regni ambita hostis naturae effectus, illis diebus [1193] a fratris infestatione quiecit (lib. iv. 34)-I would compare a passage in lib. v. 5, Eodem tempore [1194] Iohannes . . contra fratrem militabat regi Franconum, a q20 scilicet dum frater in Alemannia teneretur abstractus erat atque illectus, ut ruptis naturas legibus fraternis hostibus iungeretur. These two passages, taken together, seem to me to indicate that William specially connected John's ' hostility to nature,' or preternataral wickedness, with his

10 The clue in lib, iii 7 is, of course, quite different; it lies in the words nune nutriunt. 
conduct towards Richard; and from the words which I have not italicised in the first passage I should certainly gather that in William's opinion John had become ' $a$ monster ' before his accession to the throne, since it was his 'longing for the kingdom' which ' made' him such.

(2) The foregoing remarks are not intended as a plea to minimise the force or limit the scope of the words hostis naturae as applied by William to John. In the other place where Willism uses them-Quod ubi innotuit regi Francorrm et hosti natarae Iohanni (lib. iv. 40) - the turn of the phrase seems to me distinctly to imply that it is meant as an epithet summing up John's character- 'that monster John.' Still the particular occasion on which the epithet is used is here again, as in the former case, a display of John's disloyalty and ingratitude towards Richard. To us who know how for seventeen years after Richard's death John went on piling outrage upon outrage the epithet reads almost like an epitaph. But were not those outrages, after all, merely repeated manifestations of a character which, to a thoughtful and clearsighted onlooker, such as William of Newburgh, was already sufficiently indicated by John's earlier career? To me, nothing in John's later life is more 'monstrous' than his desertion of his father. The ciroumstances of that desertion, and the previous relations between the father and his youngest son, place it in a wholly different category from the open rebellion of Richard, or even of young Henry and Geoffrey, and reveal a lack of natural feeling, a depth of duplicity, and a far-seeing selfishness, appalling in a lad of twenty-one. Ex amlitu regni hostis naturae effectus was true of John already in 1189. It was proved true, more pablicly, over and over again, by his persistent ingratitude and treachery towards the most generous and forgiving of brothers; and we must remember that John's unscrupulous efforts to satisfy his 'longing for the kingdom' may, in one aspect, very well have seemed to William even less excusable under Richard than under Henry, for this reason: whatever schemes Henry may have entertained for John's succession were as John himself evidently sawwholly impracticable, and John's interest, therefore, in 1189 really lay with Henry's victorious opponents ; but throughout the whole of Richard's reign John practically held the position of acknowledged heir to the crown, except for the one moment in 1190 when Richard in his tresty with Tancred designated Arthur as his heir; and that exception, we may gather from lib. iv. 14, was unknown to William of Newburgh.

IV. William's chapter 'De moribus Regis Henrici' (lib. iii. 26) closes with a suggestive parallel.

Ingrati homines . . . proprii mala principis assidue carpebant; bona vero nec sudire sustinebant; quibus ati sequentis temporis sole verstio 
iam dedit intellectum. Quippe praesentium malorum experientis bonornm eius induxit memoriam. .. Salomonem quoque ... popalo minus placuisse, verbe illa ad filium eius satis insinuant, Pater turs aggravavit iugum nastrum. . . . Porro quod idem filius conquerenti popnlo, puerili levitate comminando respondit .. . quod, inquam, ab illo leviter diotum est, ad tempora nostra non leviter redundat; et tamen populus insipiens cam minori nuno querels scorpionibus caeditur quam ante annos aliquot flagellis caedebatur.

It seems hardly conceivable that this comparison with Rehoboam can be pointed at Richard. No other writer of the time gives a hint of anything in Richard's government of England which conld justify its application to him ; most aseuredly no hint of such a thing is to be found in any other part of the extant work of William himself. The wording of the pasagge is remarkable. The English Rehobosm is not nemed; we are left free to sssume, if we choose, that he was, like his prototype, the immediate saccessor of his. father, but we are not told that snch was the case; the period of his rale, and the space of time which had elspsed between the close of the raign which is contrasted with his and the date of William's criticism upon him, are veiled in what seems like intentional vagueness-tempora nostra, nunc, ante annos aliquot. In short, so far as its mere wording is concerned, the paseage may be applied to John as well as to Richard. And the sense of it applies to John far better, at least at one period of his reign. Populus insipicns cum minori nunc querela scorpionibus caeditur quam ante annos aliquot flagellis caedebatur might be said truly enough during the sears between the death of Hubert Walter and the coming of Stephen Langton, when the nation which had grumbled at the stern, yet equal, justice of Henry II and of Hubert Walter ' kept silence ' beneath the wanton tyranny of a king who 'neither feared God nor regarded man.' Our ascertained chronological data, indeed, tend to indicate (though they do not actually prove) that William's work was left onfinished before that evil time had come. Yet this passage is, I think, not absolutely irreconcilable with what seems the natural deduction from them. John's government in his later years was, no doubt, far more oppressive than in his esrlier years; but we need look no further than the pipe roll of 1200-01 to see that, in the matter of taxation and monetary exactions at least, his rale was from its very outset a chastisement with scorpions instead of whips in comparison with the rule, not only of Henry, but even of Richard.

V. The whole character of William's work precludes the idea of his having had it in hand for any great length of time. William's history, as it has come down to us, is obviously a first draft-such an admirable piece of literature cannot be called a rough draftwhich the author left both unfinished and unrevised. That it is 
unfinished appears sufficiently from its abrupt termination at a point which cannot possibly have been deliberately chosen for the conclusion of a work so excellent in literary form. That it is unrevised is shown by a number of indications, most of which are collected in Mr. Howlett's preface, and which need not be recapitulated here. But forther, the whole form and structure of the book ahows it to be a first draft in the strictest sense; not a product of research and premeditation, nor based on a collection of notes taken at various times and copied out with an intention of gradually patting them into order and shspe, but a sketch made, so to asy, straight off, with the materials which the anthor found ready to his hand in the treasure house of his own knowledge, aided, for the earlier times of English history, by some few books in the convent library, and illuminated, for the entire period with which he dealt, by the innate quality of his own mind and intellect.

The evidence as a whole, then, points (although not precluding a possibility of some few slightly later touches) to the spring of 1199 and the autumn of 1201 as the limits of time within which William's history, as we now have it, was composed. One passage indeed, there is which does not at first view seem to fit readily into these limits; but the discrepancy which it appears to involve may well be only apparent and not real. This passage occurs in lib. iv. 36, where William, after relating the expulsion of the monks from Coventry by their bishop, Hugh of Nonent, proceeds thus :-

Monschi usque in hane diem pro repocanda . . . frustra laborasse noscuntur sententía. Nondum enim ulla detestandi operis provenit correctio; sed monahis pro toleranda inopis late disperais, bons eorum ab oodem episcopo in praebendis divise seculares alerici, ipso antore, possident.

Of the restoration of the monks to Coventry there are five seemingly independent accounte-by Ralph de Diceto, Roger of Howden, Jocelyn of Brakeland, Gervase of Canterbury, and Roger of Wendover. Ralph, Howden, and Gervase state that it was performed by Archbishop Hubert in January 1198; Ralph gives the day as 18 Jan., ${ }^{11}$ Gervase as 11 Jan.; and in three manuscripts of

" MCXCVIIL. Hubertus Oantuariensis arahieplscopus clarioos quos Hngo Cestrensis episcopas, dectis monsohis, epad Coventrelam collocerverat, summi pontiflcis suctoritate munitus smovit, monsahos rolntroducens ibidem xv kalendes Pebruarii' (R. Diceto, ii. 159). 'Nonus annas regni Ricardi regia Anglieo. Anno gratiso milleximo centosimo nonagesimo octaro, qui est annus nonus regni Ricardi regie Anglise, tuit idem rex Angliso in Normannis apod Rothomagam dio Natalis Domini, ques quinta feris evenit. Rodem die Netelis dominns Habortas arahiepiscopas of insticiarius tuit in Grallie spad Hereford. . . Deinde venit Idem archlopiscopus ad Coventro, et per mendatum Coelestini summi pontificis introdurit monachos in eccletiam einsdem villa onthedralem' (Rog. Howden, iv. B6). 'MOXOVIII.-II. [ie.

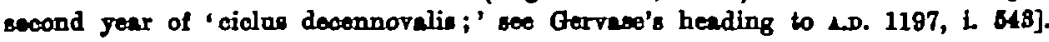


Howden there isinserted an undated letter purporting to be addressed by Pope Celestine III-who died 8 Jan. 1198-to 'the archbishop of Canterbary, the bishop of Lincoln, and the abbot of Bt. Edmands," bidding them effect the restoration. ${ }^{12}$ Jocelyn's account, ${ }^{18}$ which is dateless, runs as follows :-

Facla est commissio domini pape H. Cantuarionsi arohiepiscopo, et domino Linoolniensi, et B. abbati S. Aedmundi, de reformacione Conventrensis ecclesie et de monsohis restituendis, sine canse recognicione. Convocatis ergo partibus apud Oxneford, receperunt indices literas precatorias a domino rege, ut negocium illud poneretur in respectum. Archiepiscopo et episcopo dissimulantibus et tacentibus et quasi clericorum favorem venantibus, solus abbas aperte loquebatur, monachus pro monsahis de Conventria, eorum causam publice fovens et defendens. Et $\infty$ procurante, eo tenus processum est illa die, quod quedam simplex saisina facta fuit uni ex monechis de Conventria cum uno libro. Set dilats fuit corporalis institutio ad tempus, at sic saltem petitioni domini regis satisfaceret abbas; vero illo tempore quatrordeoim monachos de Conventria, qui ibi convenerant, recepit in hospitio suo, et sedentibus monachis ad mensam, ex uns parte domus, et ex alia parte magistris scolarum, qui summoniti fuerant, laudabatur abbss magnanimus et magnificus in expensis, neo unquam videbatur in vita sus magis letus quam tano temporis fuit, pro reverentis monastici ordinis reformandi. Instante festo 8. Hilarii, perrexit abbas cum magna hilaritate Conven. treiam, nec victus labore nec expensis, et dicebat quod si oporteret eum feretrio equitatorio portari, non remaneret. Veniente eo Conventreism, et quinque diebus expectante archiepiscopam, omnes monachos prenominatos cum servientibus eorum honorifice secum tenuit, donec creatus fuit novas prior, et monachi sollemniter introduoti essent. Qui habet aurcs audiendi, audiat frotum memoriale.

Roger of Wendover, ${ }^{14}$ under the year 1198, after recording the death of Hugh of Nonant, relates how a Coventry monk, being at Rome and hearing of that erent, forthwith presented to 'the newly elected pope, Innocent,' a petition which resultod in the 'immediate' issue of a papal mandate to Archbishop Hubert for the convent's restoration, and Hubert restored them accordingly on $18 \mathrm{Jan}$. In the Regesta of Innocent III there is a letter almost identical with the one attribated by Roger of Howden to Celestine, save that it is addressed to the archbishop of Canterbury, the bishops of Lincoln

Institait archiepiscopus Oantuariensis ex mandato Coelestini papae monachos in monastarium Coventrense iijo idus Innuarii, expalitque clericos seculares quos Hago de Nonant episcopus Cestrensis ... ante annos vili violenter eiecerat' (Gerv. Oant. i. 650). These three writers, we know, began the jear at Christmas. The Christmas Day of 1197 in our reakoning - 1198 in theirs-Fas, as Roger says, a Thursday. Both Boger and Gervase record the desth of Pope Celestine in the same year ('eodem anno ... mense Ianasrii, vito idus eingden mensis,' $R$. Howden, iv. 11 ; 'obil codem mense Innuarii,' Gerv. Cant. Lc.) Gerrase has previously (i. 460) recorded the expalsion of the monks on 9 Oct 1189.

17 R. Howdon, iv. 85-7.

it Vol, iii. pp. 126-8, ed. Core.

12 Camden Bociety's edition, pp. 69, 70. 
and Worcester, and the abbot of Tewkesbury, and is dated Romae, iii nonas Irnii. It is entered in Innocent's register under his first year. " This letter implies that the restoration of the monks, so far from having been fully accomplished in January 1198, was atill uncompleted in the June of that year. The story of the Coventry monks' restoration, as told by these varions authorities, thus remsins obscure, and in one account the obscurity intentional. The different versions of the matter are conflicting on the face of them, and we are evidently not in possession of all the facts which might enable us to reconcile them. More than one possible explanation might be suggested which would be quite compatible with William's words if they were written in 1199. The only alternative theory-that William wrote lib. iv. 36 before and apart from the rest of his history -is capsble of no plausible explanation at all, and is too unnatural and improbable to be entertained in face of the evidence which combines to indicate 1199-1201 \& the date of the composition of William's whole work.

Kate Norgate.

\section{A Lincolnshire Manor without a Demesne Farm.}

IN his kind review of $\mathrm{my}$ edition of the Cout Rolls of the Manor of Ingoldmells ${ }^{1}$ Professor Maitland encourages me to complete my. investigation, and try to establish one good instance of a considerable manor without a demesne farm and labour services from the villeins as early as 1291 . When the review appeared I had, already published in Lincolnshive Notes and Queries the account rolls of the manor of Ingoldmells for the years 1295-6, 1346-7, 1421-2, 1484-5; but, as this publication is not widely known, I venture to submit here a few further remarks on the subject. I had stated that 'during the time the rolls cover there was no demesne farm at Ingoldmells,' and I rely chiefly upon the account rolls to prove this. The earliest account rolls are for the year $1295-6$, in which there is no mention at all of any profits from a demesne farm, or of any labour services from villeins, and this is the same on all the account rolls I have found. This evidence is, I admit, negative, but when we consider the facts of the case it becomes very strong. The eccount rolls for the different duchy manore in a particular year are all bound up together, and on the

\footnotetext{
1) Innoc. III, Epp. lib. 1, no. ccxlv.

1 Anto, xvili. 780 (October 190B).

- Vol. vii. pp. 157, 167, 208 : quoting Daclyy of Lancaster, Jinisters' Accounts, bundle 1, no. 1; Duchy of Lancaster, Varions Accounts, 개, t. 25; Duch5 of Lnncaster, Ministers' Accounts, bandle 243, no. 3913; and Duchy of Lancester, Jlinisters' Accounts, bandle 248, no. 3970 .
} 